\title{
Branching Enzyme-deficiency Glycogenosis: Studies in Therapy
}

\author{
J. FERNANDES ${ }^{\star}$ and F. HUIJING \\ From the Wilhelmina Kinderziekenhuis, University of Utrecht; and the Department of Medical Enzymology, \\ Laboratory of Biochemistry, University of Amsterdam, The Netherlands
}

Type IV glycogen storage disease is caused by a deficiency of the branching enzyme, $\alpha-1,4$-glucan: $\alpha-1,4$-glucan 6-glucosyltransferase, EC 2.4.1.18 (Brown and Brown, 1966); and is characterized by the accumulation in liver, spleen, and other organs of glycogen with an abnormal structure. This glycogen has long outer chains, relatively few branch points, and gives a blue colour with iodine. It thus resembles amylopectin, and the disease is sometimes called amylopectinosis.

The disease is rare, and only 4 patients have been described (Andersen, 1956; Sidbury et al., 1962; Brown and Brown, 1966; Holleman, van der Haar, and de Vaan, 1966). We present a fifth patient, a sib of the patient described by Holleman et al. (1966). The diagnosis was made during life, by the assay of the branching enzyme activity in leucocytes.

An attempt was made to treat the child with $\alpha$-glucosidase, and with zinc-glucagon, both administered parenterally.

\section{Case Report}

This boy was referred at 5 months, with symptoms similar to those of his elder brother who had died aged 6 months (Holleman et al., 1966). The paternal grandmother and the maternal grandfather of the patient are first cousins. The mother had 4 pregnancies: 1 ending in abortion, 1 in an anencephalic child, and 2 in patients with 'amylopectinosis'. Birthweight was $4 \cdot 7 \mathrm{~kg}$.

On admission he was wasted, and the abdomen was distended by an enlarged firm liver. There was no evidence of mental retardation. He made few spontaneous movements, muscle tone was poor, and tendon reflexes depressed. The head was dolichocephalic with normal circumference; there was epicanthus and convergent strabismus.

The clinical course was that of progressive cirrhosis of the liver with wasting, ascites, splenomegaly, and intestinal haemorrhages. Hypoglycaemic attacks did

Received October 30, 1967.

* Requests for reprints should be sent to Dr. J. Fernandes, Wilhelmina Kinderziekenhuis, University of Utrecht, Nieuwe Gracht 137, Utrecht. not occur. When 11 months old he died of intercurrent respiratory infection. The findings at necropsy were similar to the case reported by Holleman et al. (1966).

Laboratory data. Raised serum levels of transaminases, aldolase, lactate dehydrogenase, especially iso-enzyme $\mathrm{V}$, were present. Total fatty acids, cholesterol, paper electrophoresis of the lipoproteins, and the fatty acid content of the serum lipids were normal. Immunoelectrophoresis showed a normal pattern. PBI was normal $(6.4 \mu \mathrm{g}$. $100 \mathrm{ml}$.). As there was muscular hypotonia the serum creatine phosphokinase activity was estimated; values of 0.8 and $1.4 \mathrm{U} / \mathrm{ml}$.* were recorded (normal $<1$ ); EMG of quadriceps muscle femorus was normal. ECG, normal.

\section{Methods}

I.iver biopsy. Liver tissue was obtained by needle biopsy after an 8-hour-fast, using the technique of Menghini (1958); vitamin $\mathrm{K}$ was given prophylactically. Four biopsies were performed, none of which was followed by bleeding. The specimen was immediately cut in three parts, one being frozen for biochemical examination, the other two fixed in ethanol $96 \%$ and formalin $10 \%$, respectively.

Leucocyte isolation. Leucocytes were isolated by the 'film' technique. The cells were homogenized and centrifuged and the protein content of the $14,000 \times \mathrm{g}$ supernatant determined (Huijing, 1964, 1968). Phosphorylase activity (Huijing, 1964), and the activity of the debranching enzyme system with the aid of glucose oxidase (Huijing, Klein Obbink, and van Creveld, 1968) were determined.

Branching enzyme. The activity of branching enzyme in leucocytes was determined by the method of Brown and Brown (1966), measuring the increase in phosphate production from glucose 1-phosphate by phosphorylase in the absence of added primer. As can be seen from Fig. 1, the phosphate production becomes linear after approximately 30 minutes. The branching enzyme activity is calculated over the linear part of the curve.

\footnotetext{
$\star \mathrm{U}=\mu \mathrm{mole}$ substrate converted/minute.
} 


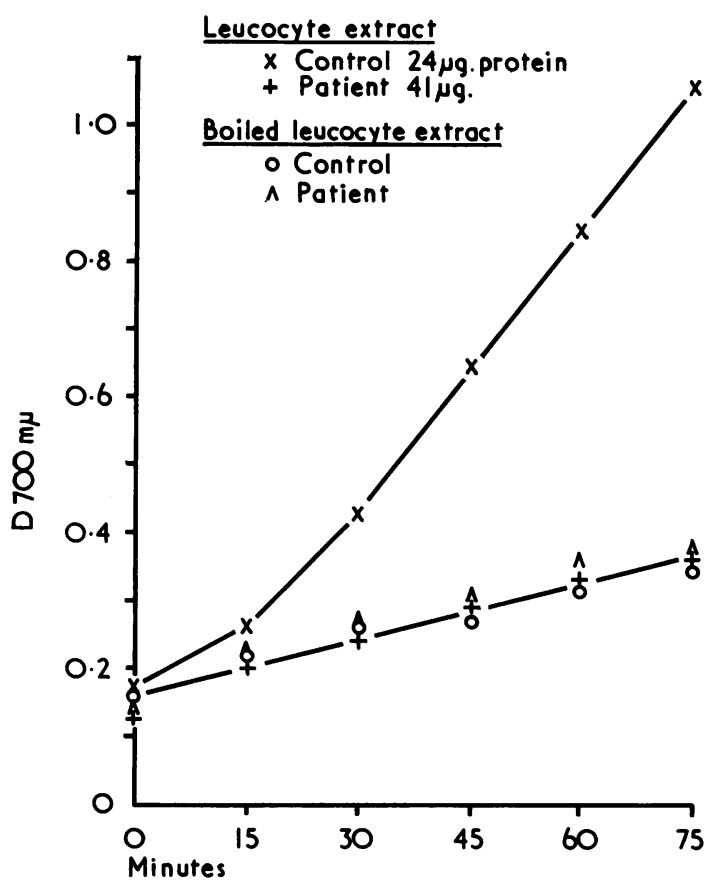

Fig. 1.-Branching enzyme activity in leucocytes. 20 $m M$ glycylglycine, $4 \mathrm{mM} A M P, 20 \mathrm{mM}$ 2-mercaptoethanol, $5 U=100 \mu \mathrm{g}$. phosphorylase a $(4 \times$ crystallized, purified over DEAE-cellulose), leucocyte protein $(14,000 \times \mathrm{g}$ supernatant), and $80 \mathrm{mM}$ glucose 1-phosphate were incubated in a final volume of $0.75 \mathrm{ml}$. at $\mathrm{pH} 6.4$ at $30^{\circ} \mathrm{C}$., according to Brown and Brown (1966). At 15-minute intervals phosphate was determined in $0.10 \mathrm{ml}$. aliquots. $A$ standard tube containing 0.25 mole of phosphate gave an extinction at $700 \mathrm{m \mu}$ of 0.420 .

Glycogen isolation and determination. Glycogen was isolated from liver tissue of leucocyte extracts with hot $30 \% \mathrm{KOH}$. It was precipitated with ethanol, dissolved, and determined with the phenol sulphuric acid method of Dubois et al. (1956).

Tolerance tests. The technique used was the oral administration (Fernandes and van de Kamer, 1965) of $2 \mathrm{~g} . / \mathrm{kg}$. glucose, galactose, or fructose in a $10 \%$ solution following a 9-hour fast. Glucose, total reducing substances, non-esterified fatty acids (NEFA), and lactate were assayed in blood samples taken at regular intervals. The glucagon tests were carried out in the same way after $0.5 \mathrm{mg}$. glucagon intramuscularly. Blood glucose was estimated with glucose oxidase (reagent set TC-M of Boehringer, Mannheim, Germany). Total reducing capacity of the blood was estimated according to Park and Johnson (1949) after deproteinization with $\mathrm{Ba}(\mathrm{OH})_{2}$ and $\mathrm{ZnSO}_{4}$. Blood fructose was estimated according to Zender and Falbriard (1966), and lactate with L-lactate dehydrogenase (Boehringer reagent set TC-B). Plasma NEFA was estimated with a micro-modification of Dole's method (Trout, Estes, and Friedberg, 1960; Fernandes and van de Kamer, 1965).

\section{Results}

Branching enzyme in leucocytes. Fig. 1 shows that a normal leucocyte extract $(14,000 \times g$ supernatant) greatly increases the rate of phosphate production from glucose 1-phosphate by purified brancher-free phosphorylase $a$ as compared to a control tube containing boiled leucocyte extract. The rate of phosphate production becomes constant after approximately 30 minutes. This is surprising, because if the number of non-reducing end-points of the endogeneously present polysaccharide is rate-limiting for the phosphorylase reaction, one would expect an exponential increase of the rate by branching enzyme, since each reaction of branching enzyme produces two non-reducing end-points out of one. For practical purposes, the activity of the branching enzyme is expressed as the difference in phosphate production between the tube with leucocyte extract and the one with boiled leucocyte extract, over the period in which the reaction is linear.

It can be seen from Fig. 1 that extract of the leucocytes of patient P.V. caused no increase over the rate of phosphate production in the control tube.

The Table shows that leucocyte extracts of normal children, and of patients with a debranching enzyme deficiency or a low activity of phosphorylase kinase (Huijing, 1968), show activities of branching enzyme within the same range as normal adults. On 3 different occasions negligible activity was found in a leucocyte extract of patient P.V. A mixture of normal leucocyte extract and that of the patient showed the same activity as the extract of normal leucocytes alone. The activities of phosphorylase and the debranching enzyme system in leucocytes of the patient were normal.

Glycogen structure. No extensive experiments to determine the structure of the glycogen in the tissues of the patient were carried out. However, $58 \%$ of the glucose l-phosphate that could be released by phosphorylase + the debranching enzyme system, was released by pure phosphorylase $b$ alone, compared with $35 \%$ with a control glycogen. This pointed to the fact that the branches were long. The enzymatic degradation was followed spectrophotometrically at $340 \mathrm{~m} \mu$ in a final volume of $1 \mathrm{ml}$. containing $80 \mathrm{mM}$ sodium phosphate buffer $(p \mathrm{H} 6 \cdot 5), 2 \mathrm{mM}$ EDTA, $10 \mathrm{mM} \mathrm{MgCl}_{2}, 2 \mathrm{mM}$ AMP, $0.2 \mathrm{mM} \mathrm{NADP}+$, approximately $10 \mu \mathrm{g}$. of glycogen and excess phosphoglucomutase, glucose 
TABLE

Activity of Branching Enzyme in Leucocytes in Patient (P.V.), in 4 Patients with Enzyme Defects, and in Normal Children and Adults

\begin{tabular}{|c|c|c|c|c|c|c|}
\hline \multicolumn{3}{|c|}{ Subject } & Sex & Age (yr.) & Metabolic Error & $\begin{array}{c}\text { Branching Enzyme } \\
\text { Activity }\end{array}$ \\
\hline $\begin{array}{ll}\text { M.Ha } & \cdots \\
\text { A.Ho } & \cdots \\
\text { J.K. } & \cdots \\
\text { J.Ho. } & \cdots \\
\text { R.B. } & \cdots \\
\text { M.Ho } & \cdots \\
\text { P.V. } & \text {. } \\
\text { 6 normal adult }\end{array}$ & $\begin{array}{l}. \\
\ldots \\
. \\
\ldots \\
\ldots \\
.\end{array}$ & $\begin{array}{l}\cdots \\
\cdots \\
\cdots \\
\cdots \\
\cdots \\
\cdots \\
\cdots\end{array}$ & $\begin{array}{l}\mathbf{F} \\
\mathbf{F} \\
\mathbf{F} \\
\mathbf{M} \\
\mathbf{M} \\
\mathbf{F} \\
\mathbf{M}\end{array}$ & $\begin{array}{c}3 \\
2 \\
1 \\
1 \\
4 \\
\text { Adult } \\
10 / 12\end{array}$ & $\begin{array}{l}\text { Nil } \\
\text { Nil } \\
\text { Debranching enzyme deficiency } \\
\text { Low phosphorylase kinase activity } \\
\text { Low phosphorylase kinase activity } \\
\text { Low phosphorylase kinase activity } \\
\text { Amylopectinosis } \\
\text { Nil }\end{array}$ & $\begin{array}{l}1 \cdot 3 \\
1 \cdot 2 \\
1 \cdot 0 \\
0 \cdot 8,0 \cdot 8 \\
0 \cdot 8 \\
0 \cdot 8 \\
0 \cdot 06,0 \cdot 00,0 \cdot 00 \\
0 \cdot 7-1 \cdot 5\end{array}$ \\
\hline
\end{tabular}

* Extra phosphorylase activity $\mu$ moles/min. per $\mathrm{mg}$. leucocyte protein $(14,000 \times g$ supernatant $)$.

Note: The values given are the mean of duplicate determinations done on two leucocyte preparations isolated from the same blood sample. If more than one determination was done on different days the value found in each experiment is given.

6-phosphate dehydrogenase, and phosphorylase. After the NADPH production stopped, a crude debranching enzyme preparation was added to measure the total amount of glucose-1-phosphate.

Glucose and galactose tolerance test. The data of oral tolerance tests with glucose and galactose are summarized in Fig. 2. The curves for both sugars closely resembled the normal pattern. NEFA too showed the normal drop. Furthermore, the rise in lactate concentration seen in patients with glucose-6-phosphatase deficiency on galactose feeding (Fernandes and van de Kamer, 1965) was absent, as in normals. During the glucose test, even lactate levels remained remarkably constant.

Fructose test. The data of the fructose tolerance test on the patient and on a normal child of the same age are summarized in Fig. 3. Fructose disappeared much more slowly from the patient's

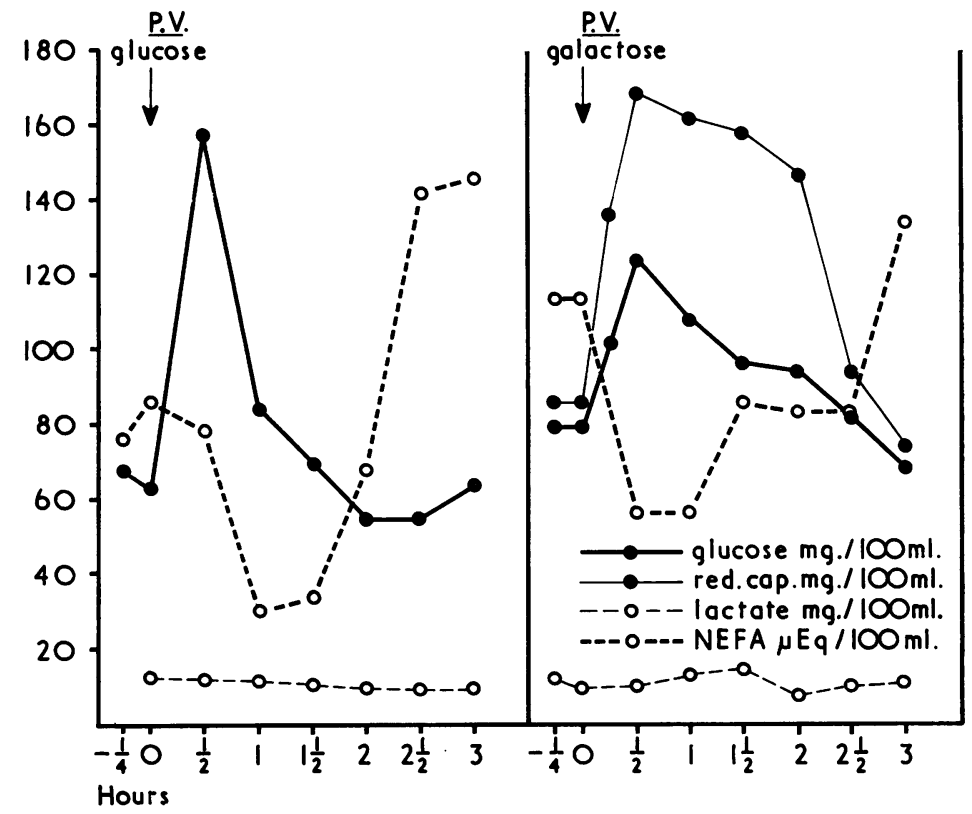

FIG. 2.-The effect of oral administration of glucose and galactose to patient P.V. Serial blood glucose; total reducing capacity; lactate; and non-esterified fatty acid levels are shown. 


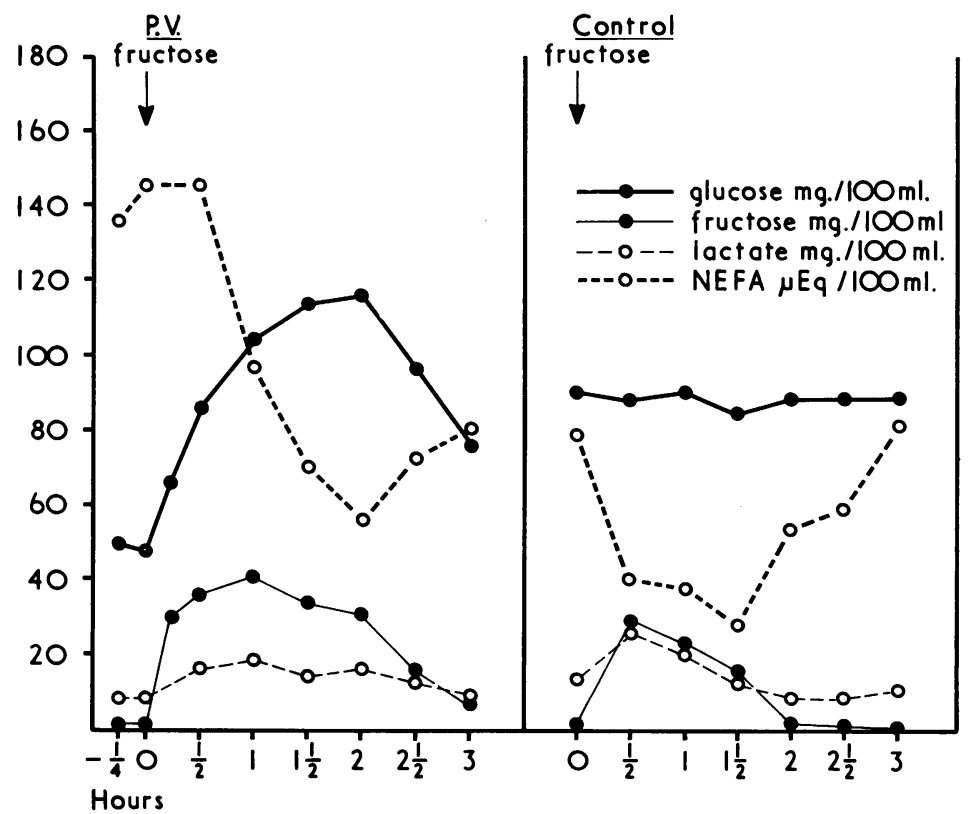

FIG. 3.-The effect of oral administration of fructose on blood glucose, fructose, lactate, and NEFA to the patient (P.V.) and normal child (control).

blood, while blood glucose levels increased in the patient but not in the control.

Glucagon test. A glucagon test at $6 \frac{1}{2}$ months resulted in a normal increase in blood glucose concentration and a decrease in NEFA (Fig. 4). When the test was repeated at $9 \frac{1}{2}$ months, no response was observed (Fig. 4).

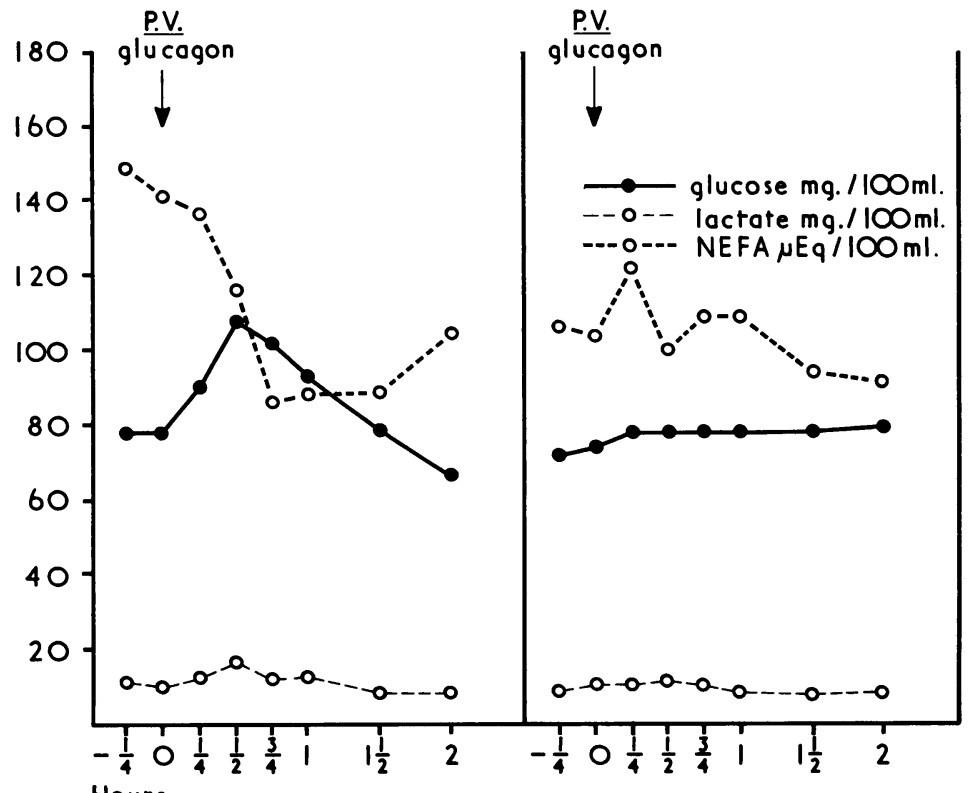

Fig. 4.-The effect of glucagon ( $0.5 \mathrm{mg}$.) intramuscularly at the age of $6 \frac{1}{2}$ months (left) and $9 \frac{1}{2}$ months (right) on patient P.V. 


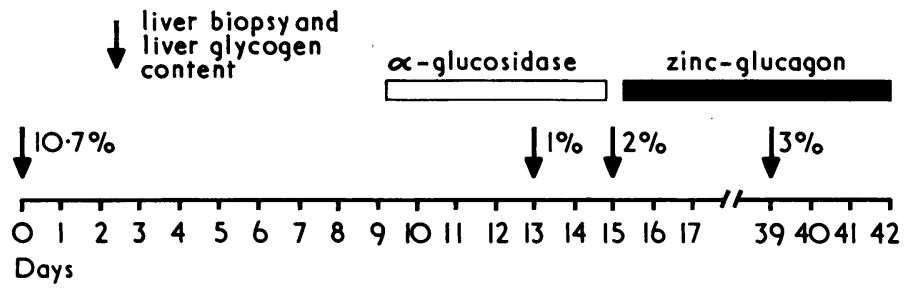

FIG. 5.-Liver glycogen content of the patient during treatment with $\alpha$-glucosidase and zinc glucagon.

\section{Treatment}

Diet therapy. A high-protein, low-carbohydrate diet with corn oil added to the milkfat was given, but resulted in no effect either on weight gain or on the progression of the cirrhotic process.

Treatment with $\alpha$-glucosidase. According to current ideas, the cirrhosis of the liver is caused by accumulation of the amylopectin-like glycogen. We therefore tried to mobilize this 'toxic' glycogen.

Baudhuin, Hers, and Loeb (1964) showed that intramuscular administration of purified fungal $\alpha$-glucosidase to a patient with type II glycogenosis (lysosomal acid $\alpha$-glucosidase deficiency) decreased the glycogen concentration of the liver from 11.5 to $8 \%$. Cuthbertson, Fleming, and Rice (1967) showed that this enzyme, when injected intraperitoneally in the rat, was rapidly taken up in several tissues, and that raised levels of $\alpha$-glucosidase could be detected in the liver for as long as 4 days.

Before treating our patient with $\alpha$-glucosidase, some preliminary experiments were carried out. Highly purified $\alpha$-glucosidase from Aspergillus niger prepared as described by Abdullah et al. (1963) was generously provided by Prof. W. J. Whelan (Dept. of Biochemistry, Royal Free Hospital School of Medicine, London W.C.1). We were able to show that this enzyme could degrade glycogen isolated from the patient's leucocytes.

In liver tissue from the patient, obtained by needle biopsy, the glycogen concentration was $107 \mu \mathrm{g} . / \mathrm{mg}$. Incubation of approximately $1 \mathrm{mg}$. tissue in $0.4 \mathrm{ml} .150 \mathrm{mM} \mathrm{NaCl}$ for $1 \mathrm{hr}$. at $37^{\circ} \mathrm{C}$. did not lower the glycogen concentration, whereas incubation in $0.4 \mathrm{ml} .150 \mathrm{mM} \mathrm{NaCl}$ containing $1 \mathrm{mg} . / \mathrm{ml}$. $\alpha$-glucosidase lowered the glycogen content to $76 \mu \mathrm{g} . / \mathrm{mg}$. tissue.

Encouraged by these results we decided to start treatment with $\alpha$-glucosidase. The child was then 10 months old, weighed $7 \mathrm{~kg}$., and was in poor condition due to the liver cirrhosis and intestinal haemorrhages. 1 g. $\alpha$-glucosidase (approximately $18,500 \mathrm{U}$ ) was dissolved in $46 \mathrm{ml}$. sterile pyrogen- free $\mathrm{NaCl}$ solution $(0 \cdot 15 \mathrm{M})$, and sterilized by passage through a Millipore filter. The enzyme solution was injected intravenously twice daily during 4 days and then 3 times daily during 2 days. Altogether the child received 14 injections totalling $56 \mathrm{ml} . \alpha$-glucosidase solution containing $1215 \mathrm{mg}$. enzyme. As can be seen in Fig. 5, the glycogen concentration of the liver decreased dramatically from $10.7 \%$ before the treatment to 1 or $2 \%$. No unfavourable reactions to the treatment were observed. The liver size did not diminish.

Treatment with zinc glucagon. Treatment with $\alpha$-glucosidase was followed by treatment with zinc glucagon intramuscularly, with the intention of preventing renewed glycogen accumulation in the liver (Sokal, 1960): $2 \mathrm{mg}$. b.d. were given for 2 days, and $1 \mathrm{mg}$. t.i.d. for the next 25 days. A liver biopsy sample obtained after 24 days of treatment contained $3 \%$ glycogen. The relevant data are shown in Fig. 5. The effect of this treatment was doubtful: the liver glycogen concentration did not increase significantly, but the child was then in a poor condition.

\section{Discussion}

Our data on the activity of branching enzyme in leucocytes confirm the results of Brown and Brown (1966), so that enzyme determinations in leucocytes provide a useful diagnostic method in 4 of the 6 types of glycogen storage disease, i.e. II, III, IV, and VI, but not $I$ and V (Huijing, 1964). An increasing number of inborn errors of metabolism can be diagnosed by means of leucocyte enzyme assays, e.g. Niemann Pick and Gaucher's disease (Kampine et al., 1967) and maple syrup urine disease (Goedde et al., 1967).

In general, no disturbances in the carbohydrate metabolism other than the accumulation of an amylopectin-like glycogen were detected. Blood sugar concentrations, several tolerance tests, and one glucagon test were normal. Of the tolerance tests only the fructose test deviated from normal: 
the probable explanation for the rise in fructose level was that portal obstruction caused the absorbed fructose to be shunted directly into the systemic circulation. The glucose increase following the fructose feed was noteworthy.

The fact that the second glucagon test showed no rise of blood glucose, unlike the first test, was not explicable. Liver biopsy obtained four days before the last test showed diffuse cirrhosis, whereas the glycogen content was $10 \cdot 7 \%$. Probably the diminished effect of glucagon was related to the progressive cirrhosis.

The effect of the injected $\alpha$-glucosidase in lowering the liver glycogen concentration is in accordance with the findings of Baudhuin et al. (1964) and Cuthbertson et al. (1967).

Recently Hug and Schubert (1967) reported briefly that purified fungal $\alpha$-glucosidase decreased the glycogen concentration in the liver of a patient with type II glycogenosis, both in the lysosomes and in the rest of the cytoplasm. The poor clinical result of treatment with $\alpha$-glucosidase in our patient is not surprising, since the injections were started when the cirrhotic process was already far advanced. The fact that the glycogen concentration of the liver fell dramatically after injections of the enzyme gives some hope that if the enzyme is administered to patients with branching-enzyme deficiency at an earlier stage of the disease, it may prevent accumulation of amylopectin. Obviously such treatment will have to be planned with great care, for the question will arise as to whether occasional large single doses of the enzyme should be given, or whether frequent small doses are less likely to lead to antibody formation. Hug and Schubert (1967) found no antibodies in their patient after 18 days of treatment.

The administration of enzymes parenterally may conceivably prove of value in treating those diseases in which such materials as glycogen, complex lipids, or mucopolysaccharides accumulate.

\section{Summary}

The fifth case is reported of glycogen storage disease type IV, characterized by accumulation of an amylopectin-like glycogen and caused by a deficiency of branching enzyme.

The abnormal glycogen and enzyme deficiency were demonstrated in leucocytes when the boy was 6 months old.
A course of purified fungal $\alpha$-glucosidase administered intravenously resulted in a decrease in the glycogen content of the liver from 11 to $2 \%$. The child died at 11 months with an infection.

The authors are grateful to Professor W. J. Whelan for providing the purified $\alpha$-glucosidase, and to Mrs. F. Fase-Fowler for technical assistance.

\section{REFERENCES}

Abdullah, M., Fleming, I. D., Taylor, P. M., and Whelan, W. J. (1963). Substrate specificity of amyloglucosidase of Aspergillus niger. Biochem. F., 89, 35P.

Andersen, D. H. (1956). Familial cirrhosis of the liver with storage of abnormal glycogen. Lab. Invest., 5, 11.

Baudhuin, P., Hers, H. G., and Loeb, H. (1964). An electron microscopic and biochemical study of type II glycogenosis. ibid., 13, 1139.

Brown, B. I., and Brown, D. H. (1966). Lack of an $\alpha$-1,4-glucan: $\alpha-1,4$-glucan 6 glycosyl transferase in a case of type IV glycogenosis. Proc. nat. Acad. Sci. (Wash.), 56, 725.

Cuthbertson, W. F. J., Fleming, I. D., and Rice, M. S. (1967). Effect of glucamylase on tissue glycogen and tissue glucamylase in the rat. Biochem. $\mathcal{F}$., 103, 307.

Dubois, M., Gilles, K. A., Hamilton, J. K., Rebers, P. A., and Smith, F. (1956). Colorimetric method for determination of sugars and related substances. Analyt. Chem., 28, 350.

Fernandes, J., and van de Kamer, J. H. (1965). Studies on the utilization of hexoses in liver glycogen disease. Pediatrics, 35, 470.

Goedde, H. W., Hüfner, M., Möhlenbeck, F., and Blume, K. G. (1967). Biochemical studies on branched-chain oxoacid oxidases. Biochim. biophys. Acta (Amst.), 132, 524.

Holleman, L. W. J., van der Haar, J. A., and de Vaan, G. A. M. (1966). Type IV glycogenosis. Lab. Invest., 15, 357.

Hug, G., and Schubert, W. K. (1967). Hepatic lysosomes in Pompe's disease: disappearance during glucosidase administration. (Abstract.) F. clin. Invest., 46, 1073.

Huijing, F. (1964). Enzymafwijkingen in het perifere bloed bij glycogeenziekte. Thesis, University of Amsterdam, V.R.B. Groningen.

- (1968). Enzymes of glycogen metabolism in leucocytes in relation to glycogen storage disease. In Control of Glycogen Metabolism. Ed. by E. Kvamme and W. J. Whelan. Academic Press, London; Universitetsforlaget, Oslo. In the press.

- Klein Obbink, H. J., and van Creveld, S. (1968). The activity of the debranching enzyme system in leucocytes: a genetic study of glycogen storage disease type III. Acta genet. (Basel), 18, 128.

Kampine, J. P., Brady, R. O., Kanfer, J. N., Feld, M., and Shapiro, D. (1967). Diagnosis of Gaucher's disease and Niemann-Pick disease with small samples of venous blood. Science, 155, 86.

Menghini, G. (1958). One-second needle biopsy of the liver. Gastroenterology, 35, 190.

Park, J. T., and Johnson, M. J. (1949). A submicrodetermination of glucose. F. biol. Chem., 181, 149.

Sidbury, J. B., Jr., Mason, J., Burns, W. B., Jr., and Ruebner, B. H. (1962). Type IV glycogenosis. Report of a case proven by characterization of glycogen and studied at necropsy. Bull. fohns Hopk. Hosp., 111, 157.

Sokal, J. E. (1960). The duration of glucagon effect. Endocrinology, $67,774$.

Trout, D. L., Estes, E. H., Jr., and Friedberg, S. J. (1960). Titration of free fatty acids of plasma: a study of current methods and a new modification. f. Lipid Res., 1, 199.

Zender, R., and Falbriard, A. (1966). Analyse colorimétrique des cétohexoses et de l'inuline par la réaction à l'acide thiobarbiturique. Clin. chim. Acta, 13, 246. 